
VOLUME 10 NOMOR 4 AGUSTUS 2021

ISSN : 2303-1514 | E-ISSN : 2598-5949

\title{
ANALYZING THE VALUE OF STUDENTS' SOCIAL CARE CHARACTER IN THE EXTRACURRICULAR OF DANCE AT GRADE III OF SDN 4 PANJUNAN KUDUS
}

\author{
Ilma Lestiana Dewi ${ }^{1}$, Fina Fakhriyah ${ }^{2}$, Sekar Dwi Ardianti ${ }^{3}$ \\ ${ }^{1,2,3}$ Universitas Muria Kudus, Kudus, Indonesia \\ 1'ilmadewi98@gmail.com, 22 fina.fakhriyah@umk.ac.id, ${ }^{3}$ sekar.dwi.ardiant@umk.ac.id
}

\section{ANALISIS NILAI KARAKTER PEDULI SOSIAL SISWA DALAM KEGIATAN EKSTRAKULIKULER SENI TARI DI KELAS III SDN 4 PANJUNAN KUDUS}

\begin{tabular}{ll}
\hline ARTICLE HISTORY & \multicolumn{1}{c}{ ABSTRACT } \\
\cline { 2 - 3 } & $\begin{array}{l}\text { Abstract: This study aimed to describe and analyze the process of learning activities and the } \\
\text { value of students' social care character that appeared during the extracurricular of dance at } \\
\text { grade III SDN } 4 \text { Panjunan Kudus in the academic year 2020/2021. The method used in this } \\
\text { research was a qualitative approach with the type of case study research to collect data and } \\
\text { information in depth. Based on research results, the data obtained were (1) there was a process } \\
\text { of learning activities starting from initial activities, core activities, and closing activities. The } \\
\text { method used in the learning process was using the training method, in which the teacher } \\
\text { provided examples of dance movements to students; then, all students followed by imitating the } \\
\text { teacher's trainer movements. (2) The value of social care character appeared during the } \\
\text { extracurricular activity in each indicator such as politeness, responsibility, and awareness. The } \\
\text { results of observations obtained a score of } 76.92 \% \text { which was included in good category. }\end{array}$
\end{tabular}

Keywords: social care characters; dance extracurricular

Accepted:

26 Juli 2021

$26^{\text {th }}$ July 2021

Published:

27 Agustus 2021

$27^{\text {th }}$ August 2021

\begin{abstract}
Abstrak: Penelitian ini bertujuan untuk mendeskripsikan serta menganalisis proses kegiatan pembelajaran dan nilai karakter peduli sosial siswa yang muncul pada saat kegiatan pembelajaran ekstrakulikuler seni tari di kelas III SDN 4 Panjunan Kudus tahun ajaran 2020/2021. Metode yang digunakan dalam penelitian ini adalah pendekatan kualitatif dengan jenis penelitian studi kasus untuk mengumpulkn data dan informasi secara mendalam. Berdasarkan hasil penelitian. data yang diperoleh yaitu (1) terdapat adanya proses kegiatan pembelajaran yang dimulai dari kegiatan awal, kegiatan inti, dan kegiatan penutup. Metode yang digunakan dalam proses pembelajaran adalah dengan menggunakan metode latihan, dimana guru memberikan contoh gerakan tari kepada siswa, kemudian diikuti oleh seluruh siswa dengan menirukan gerakan guru pelatih. (2) Adanya nilai karakter peduli sosial yang muncul pada saat proses kegiatan ekstrakulikuler seni tari disetiap indikator kesopansantunan, rasa tanggung jawab, dan kesadaran dalam hasil observasi oleh siswa tersebut telah mencapai skor sebanyak $76.92 \%$ yang termasuk dalam kategori baik.
\end{abstract}

Kata Kunci: Karakter Peduli Sosial; Ekstrakulikuler Seni Tari

CITATION

Dewi, I. L., Fakhriyah, F., \& Ardianti, S. D. (2021). Analyzing the Value of Students' Social Care Character in the Extracurricular of Dance at Grade III of SDN 4 Panjunan Kudus. Primary: Jurnal Pendidikan Guru Sekolah Dasar, 10 (4), 1038-1045. DOI: http://dx.doi.org/10.33578/jpfkip.v10i4.8216

\section{PENDAHULUAN}

Pendidikan di era globalisasi seperti ini semakin canggih dan berkembang. Pendidikan pada masa sekarang memerlukan pembangunan karakter yang di latar belakangi oleh realita ataupun kenyataan permasalahan kebangsaan yang tengah berkembang saat ini. Pembangunan karakter dapat dikatakan salah satu urutan yang sangat penting dalam pendidikan di Negara kita Indonesia. Judiani (2010) menyampaikan bahwa pembangunan karakter dan pendidikan karakter menjadi 
suatu keharusan karena pendidikan tidak hanya menjadikan peserta didik menjadi cerdas, juga mempunyai budi pekerti dan sopan santun, sehingga keberadaannya menjadi bermakna baik dirinya maupun di lingkungan masyarakat. Pada dasarnya sikap manusia terbentuk melalui proses pembelajaran dan pengalaman. Harun (2013) mengemukakan bahwa pendidikan karakter merupakan suatu sistem penanaman nilai-nilai karakter kepada peserta didik yang meliputi komponenkomponen kesadaran, pemahaman, kepedulian, dan komitmen yang tinggi untuk melaksanakan nilai-nilai tersebut. Adanya pendidikan karakter ini adalah bentuk nyata dari upaya terencana untuk menjadikan peserta didik mengenal, peduli, dan menginternalisasi nilainilai sehingga peserta didik berperilaku sebagai insan kamil, dimana pendidikan di sekolah perlu adanya pembentukan karakter peserta didik secara utuh, terpadu, dan seimbang, sesuai standar kompetensi kelulusan.

Kurniasih \& Sani

menyampaikan bahwa terdapat tiga komponen dalam pendidikan karakter yaitu petama, moral knowing atau pengetahuan tentang moral meliputi kesadaran moral, pengetahuan nilainilai moral, dan pengenalan diri. Kedua, moral feeling atau perasaan tentang moral yaitu meliputi pengetahuan aspek emosi untuk manusa berkarakter, percaya diri, kepekaan terhadap derita orang lain. Ketiga moral action, atau perbuatan moral yang merupakan hasil dari dua komponen karakter lainnya. Sejalan dengan Kementrian Pendidikan Nasional yang mengungkapkan bahwa dalam rangka mewujudkan bangsa yang berbudaya melalui penguatan nilai-nilai religius, jujur, semangat kebangsaan, disiplin, kerja keras, kreatif, mandiri, demokratis, rasa ingin tahu, semangat kebangsaan, cinta tanah air, menghargai prestasi, komunikatif, cinta damai, gemar membaca, peduli lngkungan, peduli sosial, dan bertanggung jawab, pemerintah memandang perlu adanya penguatan pendidikan karakter dengan nilai-nilai tersebut.
Pendidikan karakter dapat diintegrasikan dalam pembiasaan dan program kegiatan ekstrakulikuler. Wiliandani et al (2016) mengungkapkan bahwa pembangunan karakter diperlukan penanaman dan pendalaman nilainilai dalam kehidupan sehari-hari melalui (1) pendekatan terintegrasi dalam semua mata pelajaran, (2) pengembangan budaya satuan pendidikan, (3) pelaksanaan kegiatan kokulikuler dan ekstrakulikuler, (4) pembiasaan perilaku dalam kehidupan sehari-hari di lingkungan satuan pendidikan.

Berdasarkan hasil observasi di lapangan peneliti memilih kegiatan ekstrakulikuler sebagai obyek dalam penelitian. Kegiatan ekstrakulikuler yang dipilih yaitu seni tari. Kegiatan ekstrakulikuler seni tari dilakukan pada SDN 4 Panjunan Kudus tahun ajaran 2019/2020. Berdasarkan pengalaman peneliti saat mengikuti kegiatan pembelajaran ekstrakulikuler seni tari sering dijumpai bahwa beberapa siswa tidak mengikuti pembelajaran dengan baik. Mulai dari siswa yang tidak memperhatikan guru saat kegiatan pembelajaran, siswa yang bertingkah laku tidak baik seperti berkelahi dengan temannya, hingga kurangnya kesopanan dalam berbicara maupun bertindak terhadap guru pelatihnya. Adanya permasalahan tersebut diperkuat dengan wawancara dengan guru kelas yang menjelaskan bahwa anak-anak sering berperilaku kurang baik meskipun guruguru telah memberikan masukan hingga memberikan sanksi kepada anak tersebut. Hal tersebut dilakukan sebagai bentuk kepedulian guru agar siswa memiliki rasa jera.

Penelitian ini dilakukan karena untuk melihat nilai karakter siswa yang muncul pada saat kegiatan ekstrakulikuler seni tari. Adanya nilai karakter yang terdapat dalam kesenian tari diharapkan dapat mewujudkan perilaku siswa menjadi pribadi yang baik terutama dalam mewujudkan perilaku peduli sosial. Bentuk peduli sosial yang dimaksud dalam penelitian ini adalah sikap peduli dan rasa ingin memberi bantuan terhadap orang-orang yang ada pada saat melakukan kegiatan 
pembelajaran di sekolah. Dalam tujuan pendidikan terang diterangkan bahwa salah satu tujuan pendidikan yaitu memuat nilai-nilai kemanusiaan yang harus dimiliki oleh setiap orang pada bangsa Indonesia, salah satunya adalah sikap sosial. Berdasarkan nilai turunan nilai karakter peduli sosial yang dikemukakan oleh Mustari (dalam Agung \& Asmira, 2018) yaitu penuh kasih sayang, terhadap teman dan guru atau pelatihnya, kesantunan dalam bertindak dan bertutur kata, rasa hormat terhadap siapa saja, demokratis, kebijaksanaan, disiplin, empati, kesetaraan, suka memberi maaf, persahabatan, kesahajaan, kedermawanan, kelemahlembutan, pandai berterima kasih, pandai bersyukur, suka membantu, suka menghormati, keramah tamahan, kemanusiaan, kerendahan hati, kesetiaan, moderasi, kelembutan hati, kepatuhan, kebersamaan, toleransi dan punya rasa humor untuk menghibur teman dan gurunya. Oleh karena itu peneliti akan mengangkat permasalahan tersebut untuk dijadikan sebagai penelitian baru yang berpusat pada rendahnya nilai karakter peduli sosial siswa.

\section{KAJIAN TEORI}

Wiliandani et al (2016) menjelaskan bahwa pendidikan karakter adalah usaha sadar yang dilakukan pendidik dalam mengajarkan dan membentuk moral, etika, sikap, motivasi, perilaku, keterampilan, dan berakhlak mulia sehingga dapat menumbuhkan kemampuan yang baik untuk peserta didik. Perlu diketahui bahwa dalam UU Nomor 20 Tahun 2003 tentang Sistem Pendidikan Nasional pada Pasal 3 , yang menyebutkan: "Pendidikan nasional berfungsi mengembangkan kemampuan dan membentuk karakter serta peradaban bangsa yang bermartabat dalam rangka mencerdaskan kehidupan bangsa". Sehubung dengan hal tersebut Ardianti et al (2017) menyampaikan bahwa pendidikan karakter harus dikembangkan secara utuh dalam bingkai Sistem Pendidikan Nasional dalam rangka mencapai tujuan Pendidikan Nasional. Adanya pendidikan karakter ini adalah bentuk nyata dari upaya terencana untuk menjadikan peserta didik mengenal, peduli, dan menginternalisasi nilai-nilai sehingga peserta didik berperilaku sebagai insan kamil, dimana pendidikan di sekolah perlu adanya pembentukan karakter peserta didik secara utuh, terpadu, dan seimbang, sesuai standar kompetensi lulusan.

Nilai karakter merupakan suatu perilaku yang terbentuk atas dasar kebiasaan yang dilakukan seseorang itu sendiri. Adapun fokus nilai karakter yang terdapat pada penelitian ini adalah peduli sosial yang akan menjadi topik dalam penelitian ini dan akan dianalisis pada saat kegiatan pembelajaran ekstrakulikuler seni tari. Peduli sosial menurut Naum \& Iswahyudi (2019) adalah bentuk perasaan bertanggung jawab yang ada dalam pribadi setiap individu terkait dengan kesulitan yang dihadapi orang lain, maka individu tersebut terdorong untuk memberikan bantuan kepada orang lain dan masyarakat yang membutuhkan. Sedangkan menurut dari pendapat Agung \& Asmira (2018) kepedulian sosial merupakan sikap dan tindakan yang ingin selalu memberikan bantuan kepada orang lain dan masyarakat yang sedang membutuhkan. Sebab makhluk sosial seperti manusia akan ikut merasakan penderitaan dan kesulitan orang lain sehingga ada keinginan untuk memberikan pertolongan dan bantuan kepada orang-orang yang kesulitan.

Strategi untuk menganalisis nilai karakter siswa yang digunakan dalam penelitian ini adalah dengan menggunakan pembelajaran pada kegiatan ekstrakulikuler yang salah satunya program sekolah yang dapat dilakukan melalui kegiatan pembinaan bakat dan minat yaitu dalam bidang kesenian seperti seni tari. Ekstrakulikuler menurut Kurniasih \& Sani (2017) merupakan kegiatan yang dilakukan siswa di sekolah atau universitas di luar jam belajar kurikulum standar. Seni tari merupakan salah satu warisan budaya yang dimiliki Negara Indonesia yang harus dikembangkan dan dilestarikan oleh masyarakat yang selalu mengalami perubahan. 
Dilanjutkan oleh Wulan et al (2019) yang menyampaikan bahwa seni tari merupakan bagian dari seni budaya yang harus dilestarikan. Setiap tariannya memiliki makna dan mengandung nilai moral yang akan membawa peserta didik ikut terjun dalam pembenahan moral ataupun karakter. Fitris et al (2018) juga menyampaikan bahwa siswa yang menyukai ekstrakulikuler seni tari akan lebih semangat dan merasa senang bila waktu ekstrakulikuler tiba. Perasaan senang seperti yang digambarkan adalah merasa gembira dan lebih fokus dalam mengikuti kegiatan tersebut sehingga dapat menimbulkan keseriusan dalam mengikuti ekstrakulikuler.

Seni dalam pendidikan, lebih difungsikan sebagai media untuk memenuhi perkembangan anak, baik fisik maupun mental. Sehingga kehadiran seni dalam pendidikan sekolah mengisyaratkan bahwa seni mempunyai kedudukan, peran, atau fungsi yang penting dalam pendidikan. Terutama dalam proses pertumbuhan dan perkembangan nilai karakter yang dimiliki anak-anak. Terkait hal tersebut penelitian yang dilakukan oleh Anisa et al (2018) dengan judul Implementasi Pendidikan Karakter melalui Ekstrakulikuler Seni Tari di SDN Perwira IV Bekasi Utara memperoleh hasil penelitian yang menunjukkan bahwa adanya kegiatan ekstrakulikuler seni tari mampu memfasilitasi potensi bakat dan minat siswa dalam bidang seni, selain itu menjadikan sebagai sarana penanaman karakter yang meliputi disiplin, tanggung jawab, pantang menyerah, toleransi, kreatif, mandiri, rasa ingin tahu, religius, cinta tanah air, menghargai prestasi, bersahabat, dan peduli sosial.

\section{METODE PENELITIAN}

Metode yang digunakan adalah pendekatan kualitatif dengan jenis penelitian studi kasus yang menggambarkan tentang deskripsi dan pemahaman suatu keadaan secara mendalam tentang keseluruhan kasus. Subjek dalam penelitian ini akan dilaksanakan pada siswa kelas III yang berjumlah 12 siswa terdiri dari 4 siswa laki-laki dan 8 siswa perempuan di SDN 4 Panjunan Kecamatan Kota Kabupaten Kudus tahun ajaran 2020/2021.

Pengumpulan data dilakukan dengan teknik observasi, wawancara, catatan lapangan dan dokumentasi. Teknik observasi yang digunakan dalam penelitian ini adalah observasi partisipasif yang merupakan kegiatan observasi yang dilakukan dengan melibatkan peneliti sebagai sumber data penelitian (Sugiyono, 2016). Sehingga data yang diperoleh akan lebih lengkap dan tajam. Teknik wawancara menggunakan teknik wawancara tidak berstruktur dikarenakan wawancara dapat dilakukan secara lebih terbuka dan rileks. Wawancara dilakukan oleh peneliti dengan narasumber siswa kelas III dan wali kelas III untuk menemukan infomasi yang terkait. Catatan lapangan digunakan sebagai alat pengambilan informasi pada saat proses kegiatan pembelajaran sehingga data yang diperoleh lebih tersusun. Sedangkan teknik dokumentasi berupa tulisan maupun gambar yang berkaitan dengan kegiatan pembelajaran ekstrakulikuler.

Penelitian ini dipusatkan pada proses kegiatan pembelajaran ekstrakulikuler seni tari dan nilai karakter peduli sosial siswa dalam mengikuti pembelajaran ekstrakulikuler seni tari. Data yang terkumpul dianalisis melalui tahapan teknis analisis data yang disampaikan dalam buku Sugiyono (2016) yaitu reduksi data, penyajian data, dan verifikasi atau penyimpulan.

\section{HASIL DAN PEMBAHASAN}

\section{1) Kegiatan Pembelajaran Ekstrakulikuler Seni Tari di SDN 4 Panjunan Kudus}

Pada bagian ini akan mendeskripsikan hasil temuan penelitian mengenai kegiatan pembelajaran ekstrakulikuler seni tari. Berdasarkan hasil observasi yang telah dilaksanakan, kegiatan pembelajaran ekstrakulikuler seni tari dilaksanakan secara runtut dan tersusun. Pembelajaran yang dilakukan melalui tahapan pembelajaran yang 
memuat unsur kegiatan pembuka, kegiatan inti, dan kegiatan penutup. Pada tahapan kegiatan pembuka proses pembelajaran ekstrakulikuler seni tari di SDN 4 Panjunan Kudus dikategorikan dalam kondisi baik. Guru pelatih ekstrakulikuler seni tari memanfaatkan speker portabel yang disambungkan dengan Bluethooth pada handphone milik guru sebagai alat bantu dalam proses kegiatan pembelajaran. Sedangkan komponen penunjang seperti properti siapkan oleh siswa putri dengan membawa sampur atau selendang dan piring kecil. Sampur sendiri berfungsi sebagai pelengkap dan ciri khas yang digunakan oleh seorang penari. Sedangkan piring kecil digunakan sebagai properti untuk menunjang suatu karya tari.

Tahapan kedua yaitu kegiatan inti. Pada kegiatan inti proses pembelajaran dibagi menjadi dua kelompok besar yaitu kelompok siswa putra dan kelompok siswa putri. Pembelajaran dilakukan secara bergantian dengan metode latihan yang berlangsung dua kloter. Materi tari yang diberikan saat kegiatan pembelajaran adalah tari rampak untuk siswa putra dan tari lilin untuk siswa putri. Pemberian gerak dasar tarian pada siswa sangat diperlukan karena untuk pengetahuan awal bagi siswa agar mengetahui hal pertama yang harus dikuasai dalam mengikuti kegiatan ekstrakulikuler seni tari. Pengenalan gerak dasar tari merupakan gerakan yang melibatkan anggota badan yang meliputi gerakan tangan, kaki, kepala, serta badan.

Pada pembelajaran ekstrakulikuler seni tari, siswa putra dan siswa putri masih banyak yang mengalami kendala dalam bergerak karena berdasarkan hasil observasi siswa kelas III merupakan pertama kalinya mengikuti kegiatan ekstrakulikuler seni tari, meskipun beberapa diantaranya telah mengikuti kegiatan menari dari sejak taman kanak-kanak. Pada kegiatan tersebut pula guru pelatih lebih banyak membantu membenarkan gerakan siswa yang kurang tepat. Seperti halnya pada saat tangan dan kaki bergerak secara berlawanan guru pelatih membantu dengan menjelaskan secara perlahan. Meskipun masih banyak siswa yang melakukan kesalahan, namun semua siswa tidak sungkan dan merasa malu untuk menggerakkan anggota tubuhnya ketika menari. Belajar menari dapat dimulai dengan melihat, mengikuti, menampilkan, bahkan menciptakan atau membuat tarian dengan kreasi yang baru. Maryani (2007) mengungkapkan bahwa gerak tubuh sebagai materi yang mempunyai esensi yang terkandung didalamnya saling mempengaruhi dan memperkuat konsep tarian yang disebut dengan penyajian unsur Wiraga, Wirama, dan Wirasa yang tidak dapat dipisahkan.

Tahap pada kegiatan akhir atau penutup dilaksanakan dengan memberikan penguatan terhadap siswa agar selalu mengingat materi yang sudah dipelajari. Seluruh siswa tampak membereskan perlengkapan dan properti tari dan mengembalikan pada tempatnya masingmasing. Kegiatan ditutup dengan memimpin do'a dan berpamitan dengan guru pelatih. pada deskripsi tersebut menunjukkan bahwa kegiatan penutup dilaksanakan dengan baik. Siswa telah melakukan sikap yang seharusnya dilakukan.

\section{2) Nilai Karakter Peduli Sosial dalam Kegiatan Ekstrakulikuler Seni Tari}

Nilai karakter peduli sosial merupakan salah satu bentuk yang perlu ditanamkan oleh diri siswa. Melalui berbagai kebiasaan tentang hal dan perilaku yang baik dalam kehidupan sehari-hari sehingga siswa memiliki bentuk kesadaran dan pemahaman tinggi serta tingkat kepedulian dan dapat berkomitmen untuk menetapkan perilaku yang baik. Agung \& Asmira (2018) yang menyampaikan bahwa kepedulian sosial sebagai salah satu inti dalam implementasi pendidikan karakter. Sedangkan peduli sosial menurut Ryan et al (2017) adalah tindakan untuk peduli terhadap lingkungan sosial disekitar sehingga menjadikan siswa selalu tergerak untuk membantu sesama. Sikap dan tindakan yang selalu ingin memberi bantuan pada orang lain dan masyarakat yang membutuhkan. Nilai karakter peduli sosial 
ditanamkan melalui proses kegiatan pembelajaran ekstrakulikuler seni tari yang dilakukan oleh siswa kelas III SDN 4 Panjunan dapat dilihat melalui tiga indikator yang meliputi (1) kesopansantunan siswa, (2) rasa tanggung jawab siswa, (3) kesadaran siswa.

Hasil penelitian nilai karakter peduli sosial siswa dalam kegiatan ekstrakulikuler seni tari termasuk dalam kategori baik. Hal ini disesuaikan berdasarkan pedoman penskoran lembar observasi peduli sosial siswa dalam kegiatan pembelajaran ekstrakulikuler seni tari mencapai 76,92\%. Selama pembelajaran menari siswa tidak membeda-bedakan teman. Siswa memberikan respon terhadap guru dengan menghargai guru pada saat memberikan penjelasan dan arahan. Pada saat pembelajaran siswa selalu merespon intruksi dari guru. Respon yang ditunjukkan siswa yakni bahwa siswa sangat antusias dan semangat untuk menari tari tradisional yang merupakan salah satu bentuk rasa bangga terhadap kesenian tradisional. Meskipun terkadang melakukan kesalahan saat menari tidak membuat siswa merasa malu untuk menggerakkan tubuhnya. Arisyanto et al (2018) menjelaskan bahwa melalui pembelajaran ekstrakulikuler seni tari dapat menumbuhkan sikap menghargai orang lain, menghargai perbedaan, menghargai dirinya sendiri dan bersikap percaya diri.

Bentuk karakter yang tampak pada setiap tahapan pembelajaran ekstrakulilkuker seni tari mulai dari kegiatan awal, kegiatan inti dan kegiatan akhir pembelajaran yang dilakukan oleh siswa mengalir berdasarkan karakter yang telah dimiliki seseorang tersebut. Ekstrakulikuler seni tari merupakan suatu kegiatan yang dapat menumbuhkan karakater peduli sosial pada diri siswa karena sebagai bentuk kesadaran manusia bahwa setiap makhluk sosial tidak dapat hidup sendiri. Sifat saling tergantung antara satu individu dengan individu lain dibutuhkan oleh setiap manusia. Melalui kegiatan ekstrakulikuler seni tari seorang siswa mampu menunjukkan rasa simpati dan empati yang tinggi terhadap seseorang disekitar, sebagai contoh pada saat siswa mengalami kesulitan dalam mengikuti pembelajaran ekstrakulikuler seni tari tidak segan-segan temannya yang melihat segera memberikan bantuan untuk mengajari gerakan yang belum dipahaminya. Karakter peduli sosial dapat dilakukan oleh siapa saja dan tanpa memandang satu dengan yang lainnya, baik dari segi status, ras suku, dan agama.

Jazuli (2010) menjelaskan bahwa kegiatan ekstrakulikuler seni tari memberikan kontribusi sebagai wadah atau ruang untuk berekspresi, pengembangan potensi kreatif, peningkatan kepekaan ras, menimbulkan rasa percaya diri, dan pengembangan wawasan budaya pada pengembangan pribadi anak. Pembelajaran kesenian tari mengandung nilai karakter yang berasal dari maksud dan tujuan gerakan pada tarian yang memiliki sebuah arti yang mendidik. Tari rampak dan tari lilin memiliki gerakan yang sederhana, dinamis, gembira serta lincah. Adapun ragam gerak dalam tari rampak memiliki nilai karakter yang meliputi karakter religius, disiplin, tanggung jawab, peduli sosial, dan rasa hormat. Sedangkan ragam gerak dalam tari lilin memiliki nilai karakter Tanggung jawab, peduli sosial, dan kerja keras. Hal tersebut telah disesuaikan berdasarkan unsur seni tari wiraga, wirama, wirasa dengan nilai karakter dan estetika dalam tarian tersebut. Wiraga merupakan keterampilan gerakan dan terungkap melalui keselarasan atau kepekaan unsur wirama yang artinya irama dalam tarian serta memiliki penjiwaan yang sesuai dengan masing-masing karakter dalam suatu karya tari.

Penumbuhan karakter sikap siswa tidak luput dengan adanya pembiasaanpembiasaan dan pembinaan. Pembiasaan dan pembinaan tersebut melalui berbagai bentuk kegiatan di dalamnya, dengan adanya kegiatan-kegiatan tersebut maka karakter setiap anak akan muncul dan terbentuk dengan sendirinya. Kegiatan pembiasaan dan pembinaan yang diberikan oleh gurunya sendiri merupakan bentuk wadah untuk siswa 
supaya menjadikan seseorang memiliki sikap peduli yang tinggi terhadap setiap orang yang ada disekitarnya karena warga negara yang baik adalah warga negara yang mampu bertoleransi terhadap sesama. Oleh karena itu guru merupakan salah satu point terpenting dalam pendidikan karakter peduli sosial. Hal ini disesuaikan dengan semboyan Ki Hajar Dewantara yaitu "Ing Ngarsa Sung Tuladha" yang artinya pendidik di depan memberi contoh, contoh itu teladan. Guru menjadi fokus utama sebagai keberhasilan seorang siswa karena guru merupakan panutan siswa dan masyarakat menjadikan siswanya menjadi seorang yang berintelektual dan berkarakter. Naum \& Iswahyudi (2019) menyampaikan bahwa karakter yang harus dimiliki oleh seseorang dalam membentuk warga negara yang cerdas adalah dengan memiliki sikap yang peduli terhadap kondisi sekitar. Nilai karakter itulah yang akan tertanam menjadi suara hati untuk selalu memberikan bantuan dan menjaga sesama.

\section{SIMPULAN DAN REKOMENDASI}

Berdasarkan pemaparan di atas dapat disimpulkan bahwa kegiatan penelitian pada pembelajaran ekstrakulikuler seni tari pada siswa kelas III tahun ajaran 2020/2021 yang melalui tiga tahapan yaitu kegiatan awal, kegiatan inti, dan kegiatan penutup dan nilai karakter peduli sosial siswa yang muncul pada saat kegiatan pembelajaran ekstrakulikuler seni tari mencapai 76,92\% termasuk dalam kategori baik. Sebagian besar sikap dari aspek-aspek yang diamati tampak adanya disetiap tahapan pembelajaran yang dilakukan oleh siswa dan guru. Sikap yang ditunjukkan oleh siswa pada saat kegiatan pembelajaran ekstrakulikuler seni tari merupakan karaker yang dimiliki masingmasing siswa tanpa adanya paksaan dari pihak manapun.

Sebagai peneliti akan memberikan saran bahwa sebagai makhluk sosial kita selalu bersikap dan berperilaku yang baik sebagai bentuk pembiasaan dan pembelajaran bagi diri agar agar dapat berguna bagi nusa dan bangsa serta tetap menjaga dan melestarikan kesenian budaya sebagai bentuk kecintaan kita terhadap tanah air.

\section{DAFTAR PUSTAKA}

Agung, P dan Asmira, Y. (2018). Pengembangan Model Pendidikan Karakter Peduli Sosial melalui Metode Bermain Peran di TK Tunas Mekar Indonesia Bandar Lampung. Jurnal Caksana-Pendidikan Anak Usia Dini. 1(2). 139-158.

Anisa, N. R., Nurafifah, FF., Munawaroh, S. (2018). Implementasi Pendidikan Karakter melalui Ekstrakulikuler Seni Tari di SDN Perwira IV Bekasi Utara. Prosiding Seminar dan Diskusi Nasional Pendidikan Dasar. 18-23.

Ardianti, S. D., Wanabuliandari, S., Raharjo, S. (2017). Peningkatan Perilaku Peduli Lingkungan dan Tanggung Jawab Siswa melalui Model EJAS dengan Pendekatan Science Edutainment. Jurnal Ilmiah "Pendidikan Dasar". 4(1). 1-7.

Arisyanto, P., Sundari, RS., dan Untari, MFA. (2018). Pengembangan Ekstrakulikuler Tari untuk Penanaman Karakter bagi SIswa SD Negeri Gayamsari 02 Semarang. Jurnal Pendidikan dan Kajian Seni. 3(1). 1-13.

Fitris, A., \& Iriana. (2018). Minat Siswa Terhadap Seni Tari dalam Kegiatan Ekstrakulikuler Tari di SMP Pembangunan Laboratorium UNP. EJurnal Sendratasik. 6(2). 50-57.

Harun, C. (2013). Managemen Pendidikan Karakter. Jurnal Pendidikan Karakter. 3 (3), 302-308.

Jazuli, M. (2010). Model Pembelajaran Tari Pendidikan Pada Siswa SD/MI. Journal Of Art Reseach and Education. 10(2). 1-18.

Judiani, S. (2010). Implementasi Pendidikan Karakter di Sekolah Dasar melalui Penguatan Pelaksanaan Kurikulum. 
ISSN : 2303-1514 | E-ISSN : 2598-5949

Jurrnal Pendidikan dan Kebudayaan. 16(3). 280-289.

Kurniasih, I., dan Sani, B. (2017). Pendidikan Karakter Internalisasi dan Metode Pembelajaran di Sekolah. Yogyakarta: CV. Kata Pena.

Maryani, D. (2007). Wiraga Wirama Wirasa dalam Tari Tradisi Gaya Surakarta. Jurnal Ilmu dan Seni- ISI Surakarta. 5(1). 28-41.

Naum, E dan Iswahyudi, D. (2019). Peran Kegiatan Ekstrakulikuler Palang Merah Remaja dalam Pembentukan Karakter Peduli Sosial Siswa. Prosiding Seminar Nasional Pendidikan dan Pembelajaran Bagi Guru dan Dosen. 3. 236-241.
Ryan, AF., Zainuddin, Atok, RA. (2017). Penguatan Karakter Rasa Ingin Tahu dan Peduli Sosial melalui Discovery Learning. Jurnal Teori dan praktis Pembelajaran IPS. 2(2). 27-36.

Sugiyono. (2016). Metode Penelitian Pendidikan. Bandung: CV. Alfabeta

Wiliandani, AM., Wiyono, BB., Sobri, AY. (2016). Pendidikan Karakter dalam Pembelajaran di Sekolah Dasar. Jurnal Pendidikan Humainora. 4(3). 132-142.

Wulan, N, Wakhyudin, H, Rahmawati, I. (2019). Ekstrakulikuler Seni Tari dalam Membentuk Nilai Karakter Bersahabat. Indonesian Values and Character Education Journal. 2 (1), 28-35. 